\title{
Half life of chromium in serum and urine in a former plasma cutter of stainless steel
}

\author{
Rolf Petersen, Jane Frølund Thomsen, Niels Kjærgaard Jørgensen, Sigurd Mikkelsen
}

\begin{abstract}
For 8 years chromium in serum and urine has been followed up in a former plasma cutter of stainless steel who was exposed to airborne dust and fumes containing chromium during this work. After the first examination for serum chromium the exposure ended. Serum chromium concentration has been measured seven times during the period and was initially very high and has subsequently dropped slowly. The half life was 40 months in serum. Urinary chromium has been measured five times. The half life was 129 months in urine. The study shows that exposure to airborne dust and fumes containing chromium may cause accumulation of chromium in the body, and that when exposure ends, elimination of chromium is very slow. Previous studies suggest that chromium mainly accumulates in the lungs.

(Occup Environ Med 2000;57:140-142)
\end{abstract}

Keywords: chromium half life; plasma cutting; stainless steel

Department of Occupational Medicine, Glostrup

Hospital, University of Copenhagen, DK-2600

Glostrup, Denmark

$\mathrm{R}$ Petersen

J F Thomsen

S Mikkelsen

Department of

Occupational

Medicine, Slagelse

Hospital, DK-4200

Slagelse, Denmark

$\mathrm{R}$ Petersen

Department of Occupational Medicine, Nykøbing

Falster Hospital, DK-4800 Nykøbing F,

Denmark

N K Jørgensen

Correspondence to: Dr Rolf Petersen,

Arbejdsmedicinsk Afdeling, Centralsygehuset i Slagelse, DK-4200 Slagelse, Denmark email scrope@vestamt.dk

Accepted 16 September 1999 cluding hexavelent chromium, through the inhaled air. ${ }^{1}$

Hexavalent chromium has a carcinogenic effect as well as other toxic effects. ${ }^{2}$

\section{Case report}

On 1 November 1990, a 44 year old man was examined for work related mucous membrane symptoms and eczema. From 1960 to 1976 he had worked in the metal industries, mainly carrying out welding and flame cutting of ordinary iron but also, to a minor extent, plasma cutting of stainless steel. From 1976 to 1983 he had worked as a ship's painter, during which period there was no known exposure to chromium. From 1983 to 1990 he had been working with plasma cutting of stainless steel. The workshop in which the work was carried out was about $200 \mathrm{~m}^{2}$, the floor to ceiling height being $4 \mathrm{~m}$. There were three plasma cutting machines in the room, which were exclusively used for plasma cutting of stainless steel. Air extraction took place from the bottom of the cutting tables on which the plates were placed during the cutting. There was no mechanical supply of fresh air into the room. Visible fumes were often seen in connection with the cutting. No personal protection equipment-such as a mask or gloves-was used. When the premises were inspected, the hygiene conditions were found to be poor, with considerable formation of dust and poor facilities for personal hygiene. Measurements for chromium in dust samples collected showed high concentrations of chromium.

As part of the clinical examination of the patient, serum chromium was measured on 9 November 1990 in the morning about 18 hours after the last exposure. Four days later the patient had a mild apoplexia cerebri and had to stop working. He has not been exposed to chromium since and we therefore have had the opportunity to study the development of chromium in the serum and urine for the subsequent 8 years.

Serum chromium has been measured seven times over the years, firstly on 9 November 1990 and for the last time on 13 October 1998. Urinary chromium has been measured five times, firstly on 13 February 1991 and for the last time on 5 May 1998.

Venous blood samples for measurement of serum concentrations of chromium were 


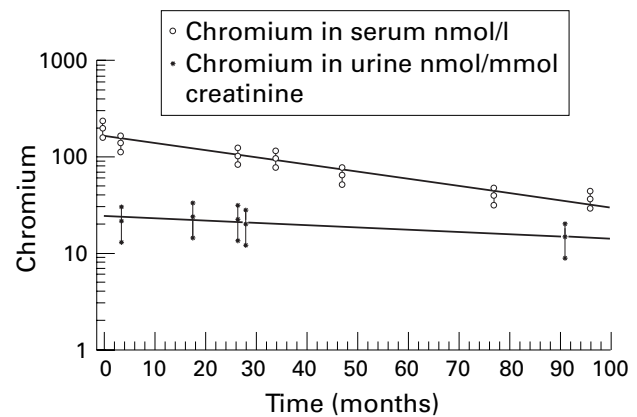

Serum and urinary chromium measured during an 8 year period in a former plasma cutter of stainless steel. The vertical lines indicate $95 \%$ CIs. The other lines are vertical lines indicate $95 \%$ CIs. The other lines are
regression lines fitted to serum and urinary chromium. Half life was 40 months for serum chromium and 129 months for urinary chromium. The regression equations were:

$\log _{10}$ (serum chromium) $=-0.007575 \times$ month +2.220697 .

The slope was different from $0(p<0.0001)$.

$\log _{10}$ (urinary chromium) $=-0.002336 \times$ month +1.379243 .

The slope was different from $0(p=0.0212)$.

obtained in a hospital laboratory and collected in blood collection tubes for measurement of trace elements. Serum chromium was measured by electrothermic atomic absorption spectrometry (graphite furnace technique, GF-ASS) with matrix matched standards. The matrix modifier contained 5\% Triton-X-100. The analytical method was controlled with external and internal control samples. The analysis used was the same throughout the period of follow up (Medi-Lab, Copenhagen). The reference value was $<12 \mathrm{nmol} / \mathrm{l}$. This value was based on a study where serum chromium was analysed in 21 healthy non-exposed people (Grosch K, Medi-Lab Copenhagen, personal communication). The highest value was 11.5 $\mathrm{nmol} / \mathrm{l}$.

The urine samples were voided in acid cleaned polyethylene bottles. Urinary chromium was measured by Zeeman atomic absorption spectrometry under external and internal quality control (Danish National Institute of Occupational Health, Copenhagen). ${ }^{3}$ The reference value for urinary chromium was $<1.3 \mathrm{nmol} / \mathrm{mmol}$ creatinine. Creatinine concentration in urine was measured by Jaffe's reaction. ${ }^{3}$ The analyses were the same during the period of follow up.

The first serum chromium concentration was $199 \mathrm{nmol} / 1$ and the last one $36 \mathrm{nmol} / 1$. The first urinary chromium concentration was $21.5 \mathrm{nmol} / \mathrm{mmol}$ creatinine and the last one $14.4 \mathrm{nmol} / \mathrm{mmol}$ creatinine. Serum creatinine was normal.

The figure shows the correlation between months since last exposure and $\log _{10}$ serum and urinary chromium with $95 \%$ confidence intervals (95\% CIs). The regression lines are fitted to $\log _{10}$ serum and urinary chromium. The half life was calculated from the equation $\mathrm{T}_{1 / 2}=\left(\log _{10} 2\right) / \mathrm{S}$, where $\mathrm{S}$ is the slope of the regression lines. The half life for serum chromium was 40 months and 129 months for urinary chromium.

\section{Discussion}

Serum chromium and urinary chromium found in our patient were very high compared with non-exposed people.
In their literature study, Brune et al (1993) found 53 studies dealing with normal concentrations for serum chromium and 58 studies dealing with normal concentrations for urinary chromium. The range of the arithmetic mean values was $1-3 \mathrm{nmol} / 1$ for serum chromium and $0.2-1 \mathrm{nmol} / \mathrm{mmol}$ creatinine for urinary chromium in people with no known exposure to chromium. ${ }^{4}$

The high concentrations in our patient cannot be explained by contamination. The blood and urine samples were taken in a hospital laboratory with special tubes and bottles for trace element measurement. Previous studies have shown that vacutainer needles used for venipuncture do not add measurable chromium to the blood $(<1.7 \mathrm{nmol} / \mathrm{l}) .^{5} \mathrm{~A}$ non-exposed worker from the same company had a normal urinary chromium concentration with the same sampling and analysing technique. So contamination can be considered to be negligible.

The half life for serum chromium and urinary chromium was very long in our patient. There was no sign of renal disease and the slow elimination cannot be explained by decreased renal function.

In a study where elimination of chromium was studied in people given a bolus dose in drinking water the half life was much shorter, $<40$ hours, and was longest after ingestion of hexavalent chromium. ${ }^{5}$ In our patient chromium was not ingested but inhaled as fumes and dust. The half life therefore reflects the absorption and elimination from the lungs.

No previous studies of chromium elimination in plasma cutters have been found. However, the agents found in the fumes from stainless steel welding are the same as those in fumes from plasma cutting of stainless steel. ${ }^{13}$ In the breathing zone of 13 plasma cutters the mean concentration of total chromium was 129 $\mu \mathrm{g} / \mathrm{m}^{3}\left(20-440 \mu \mathrm{g} / \mathrm{m}^{3}\right)$ and the mean concentration of hexavalent chromium $17 \mu \mathrm{g} / \mathrm{m}^{3}(<1-40$ $\left.\mu \mathrm{g} / \mathrm{m}^{3}\right) .{ }^{1}$ Although these concentrations are higher than those found during welding in stainless steel, ${ }^{3}$ the absorption, accumulation, and elimination of chromium in plasma cutters of stainless steel may be compared with those in welders of stainless steel.

In animal tests in which rats were exposed to welding fumes containing chromium, an initial rapid elimination from the lungs of a small part of the inhaled chromium was found on the first day. Subsequently a long half life was found in the lungs for the rest of the chromium - that is, most of it. In two studies the long half life was found to be about 50 days and in one study it was 240 days. ${ }^{6-8}$

Several studies of the excretion of chromium in the urine of welders who carried out manual metal arc welding of stainless steel (MMA/SS) have been made. These studies have shown that the urinary chromium concentration 16 hours after exposure was about $64 \%$ of the highest concentration measured immediately after exposure. Sixty four hours after exposure the urinary concentration was about $56 \%$ of the peak value. On the basis of these findings the initial half life for urinary chromium excretion was estimated to be about 7 hours. ${ }^{9}$ This figure 
corresponds to the half life as calculated by Welinder et al (1983), where the initial mean half life was 7 hours with a variation ranging from 4 to 35 hours. ${ }^{10}$

In follow up studies carried out 1 month after exposure a second phase with a half life of 20-27 days has been found. In the study carried out by Welinder et al. (1983) the half life for four subjects was 14 days, 33 days in two subjects, and infinite in the two other subjects. ${ }^{10}$ In nine retired welders the concentration of chromium in the urine was found to be increased, being $7 \mu \mathrm{mol} / \mathrm{mol}$ creatinine on average. This was not significantly different from concentrations found in active welders after 4 weeks holiday ( $9 \mu \mathrm{mol} / \mathrm{mol}$ creatinine). This indicates that there is an extremely slow phase of urinary elimination of chromium after exposure to MMA/SS welding fumes from stainless steel.

Other components of MMA/SS welding fumes have long half lives as well. Magnetopneumographic studies, for example, show that magnetic dust is eliminated from the lungs at a half life rate of 3-5 years in MMA/SS welders who have welded light steel. ${ }^{11}$

Results are available from a few necropsy studies of chromium concentrations in different organs of subjects exposed to chromium compared with a control group. Hyodo et al examined tissue samples from various organs in a worker who had worked with the production of chromate for 30 years until 10 years before his death and had thus been exposed to dust containing chromium. ${ }^{12}$ The highest concentration was found in lung tissue $(3.56 \mu \mathrm{g} / \mathrm{g}$ compared with $\leqslant 0.1 \mu \mathrm{g} / \mathrm{g}$ in other organs). The concentration found in lung tissue was about 20 times as high as the average of five subjects in a control group. In the other organs, concentrations were about twice as high as those of the control group. Raithel et al examined the lung tissue of two former welders who had welded stainless steel. ${ }^{13}$ Chromium concentrations in their lungs were 10-15 times as high as those in 68 controls. There was no information available about the intensity or duration of exposure or the time interval from the end of exposure to the time when the examination was carried out. The necropsy examinations showed that chromium accumulated in the lungs and was eliminated slowly.

On the basis of these studies, there seem to be three successive half life periods in the urinary excretion of chromium in MMA/SS welders: 7 hours, $15-30$ days, and 3-5 years. The quantity of body chromium in each phase must depend on the quantity accumulated in the body. If considerable accumulation has occurred, most of the chromium is found in the slowest phase.

Our patient had accumulated chromium in the body over a long period. Most of the chromium found in the body of our patient was therefore in the slowest phase. The regression lines of serum and urinary chromium over time therefore show the elimination in the slowest phase.

The first blood sample was taken 18 hours after last exposure. The chromium inhaled 2 days before therefore was in a faster phase. When calculating the regression line excluding the first serum chromium, the half life of serum chromium was slightly longer, 43 months.

The half life of urinary chromium was considerably longer than the half life of serum chromium, 129 months versus 40-43 months. This difference we cannot explain.

1 Van der Wal JF. Further studies on the exposure of welders to fumes, chromium, nickel and gases in Dutch industries: plasma welding and cutting of stainless steel. Ann Occup plasma welding and cutt

2 International Agency for Research on Cancer. IARC monographs on the evalutation of carcinogenic risks to humans. Chromium, nickel and welding. Vol 49. Lyon: IARC, 1990.

3 Knudsen LE, Boisen T, Christensen JM, et al. Biomonitoring of genotoxic exposure among stainless steel welders. Mutat Res 1992;279:129-43.

4 Brune D, Aitio A, Nordberg G, et al. Normal concentrations of chromium in serum and urine-a TRACY project. Scand 7 Work Environ Health 1993;19(suppl 1):39-44.

5 Kerger BD, Paustenbach DJ, Corbett GE, et al. Absorption and elimination of trivalent and hexavalent chromium in humans following ingestion of a bolus dose in drinking water. Toxicol Appl Pharmacol 1996;141:145-58

6 Kalliomaki PL, Kiilunen M, Vaaranen V, et al. Retention of stainless steel manual metal arc welding fumes in rats. $\mathcal{F}$ Toxicol Environ Health 1982;10:223-32.

7 Kalliomaki PL, Lakomaa E, Kalliomaki K, et al. Stainless steel manual metal arc welding fumes in rats. Br f Ind Med 1983;40:229-34.

8 Kalliomaki PL, Tuomisaari M, Lakomaa EL, et al. Retention and clearance of stainless steel shield gas welding fumes in rat lungs. Am Ind Hyg Assoc F 1983;44:649-54.

9 Aitio A, Jarvisalo J, Kiilunen M, et al. In: Clarkson TW, Friberg L, Sager PR, eds. Biological monitoring of toxic metals. New York: Plenum Press, 1988

10 Welinder $\mathrm{H}$, Littorin $\mathrm{M}$, Gullberg B, et al. Elimination of chromium in urine after stainless steel welding. Scand $\mathcal{F}$ Work Environ Health 1983;9:307-403.

11 Kalliomäki P-L, Kalliomäki K, Rakhonen E, et al. Magnetopneumography - lung retention and clearance of manual metal arc welding fumes based on experimental and human data. In: Weinberg H, Stroink G, Katila K, ed. Biomagnetism: application and theory. Proceedings of the 5 th World Conference on Biomagnetism. Vancouver. Oxford: Pergamon Press, 1985.

12 Hyodo K, Suzuki S, Furya N, et al. An analysis of chromium, copper, and zinc in organs of a chromate worker. Int Arch Occup Environ Health 1980;46:141-50.

13 Raithel H-J, Schaller K-H, Kraus T, et al. Biomonitoring of nickel and chromium in human pulmonary tissue. Int Arch Occup Environ Health 1993;65: S197-200. 